\title{
Long Foraging Movement of a Denning Tundra Wolf
}

\author{
PAUL F. FRAME,,$^{1,2}$ DAVID S. HIK, ${ }^{1}$ H. DEAN CLUFF ${ }^{3}$ and PAUL C. PAQUET ${ }^{4}$
}

(Received 3 September 2003; accepted in revised form 16 January 2004)

\begin{abstract}
Wolves (Canis lupus) on the Canadian barrens are intimately linked to migrating herds of barren-ground caribou (Rangifer tarandus). We deployed a Global Positioning System (GPS) radio collar on an adult female wolf to record her movements in response to changing caribou densities near her den during summer. This wolf and two other females were observed nursing a group of 11 pups. She traveled a minimum of $341 \mathrm{~km}$ during a 14-day excursion. The straight-line distance from the den to the farthest location was $103 \mathrm{~km}$, and the overall minimum rate of travel was $3.1 \mathrm{~km} / \mathrm{h}$. The distance between the wolf and the radio-collared caribou decreased from $242 \mathrm{~km}$ one week before the excursion to $8 \mathrm{~km}$ four days into the excursion. We discuss several possible explanations for the long foraging bout.
\end{abstract}

Key words: wolf, GPS tracking, movements, Canis lupus, foraging, caribou, Northwest Territories

RÉSUMÉ. Les loups (Canis lupus) dans la toundra canadienne sont étroitement liés aux hardes de caribous des toundras (Rangifer tarandus). On a équipé une louve adulte d'un collier émetteur muni d'un système de positionnement mondial (GPS) afin d'enregistrer ses déplacements en réponse au changement de densité du caribou près de sa tanière durant l'été. On a observé cette louve ainsi que deux autres en train d'allaiter un groupe de 11 louveteaux. Elle a parcouru un minimum de $341 \mathrm{~km}$ durant une sortie de 14 jours. La distance en ligne droite de la tanière à l'endroit le plus éloigné était de $103 \mathrm{~km}$, et la vitesse minimum durant tout le voyage était de $3,1 \mathrm{~km} / \mathrm{h}$. La distance entre la louve et le caribou muni du collier émetteur a diminué de $242 \mathrm{~km}$ une semaine avant la sortie à $8 \mathrm{~km}$ quatre jours après la sortie. On commente diverses explications possibles pour ce long épisode de recherche de nourriture.

Mots clés: loup, repérage GPS, déplacements, Canis lupus, recherche de nourriture, caribou, Territoires du Nord-Ouest

Traduit pour la revue Arctic par Nésida Loyer.

\section{INTRODUCTION}

Wolves (Canis lupus) that den on the central barrens of mainland Canada follow the seasonal movements of their main prey, migratory barren-ground caribou (Rangifer tarandus) (Kuyt, 1962; Kelsall, 1968; Walton et al., 2001). However, most wolves do not den near caribou calving grounds, but select sites farther south, closer to the tree line (Heard and Williams, 1992). Most caribou migrate beyond primary wolf denning areas by mid-June and do not return until mid-to-late July (Heard et al., 1996; Gunn et al., 2001). Consequently, caribou density near dens is low for part of the summer.

During this period of spatial separation from the main caribou herds, wolves must either search near the homesite for scarce caribou or alternative prey (or both), travel to where prey are abundant, or use a combination of these strategies.

Walton et al. (2001) postulated that the travel of tundra wolves outside their normal summer ranges is a response to low caribou availability rather than a pre-dispersal exploration like that observed in territorial wolves (Fritts and Mech, 1981; Messier, 1985). The authors postulated this because most such travel was directed toward caribou calving grounds. We report details of such a long-distance excursion by a breeding female tundra wolf wearing a GPS radio collar. We discuss the relationship of the excursion to movements of satellite-collared caribou (Gunn et al., 2001), supporting the hypothesis that tundra wolves make directional, rapid, long-distance movements in response to seasonal prey availability.

\section{STUDY AREA}

Our study took place in the northern boreal forest-low Arctic tundra transition zone $\left(63^{\circ} 30^{\prime} \mathrm{N}, 110^{\circ} 00^{\prime} \mathrm{W}\right.$; Fig. 1; Timoney et al., 1992). Permafrost in the area changes from discontinuous to continuous (Harris, 1986). Patches of spruce (Picea mariana, P. glauca) occur in the southern portion and give way to open tundra to the northeast. Eskers, kames, and other glacial deposits are scattered

\footnotetext{
${ }^{1}$ Department of Biological Sciences, University of Alberta, Edmonton, Alberta T6G 2E9, Canada

${ }^{2}$ Corresponding author: pframe@ualberta.ca

${ }^{3}$ Department of Resources, Wildlife, and Economic Development, North Slave Region, Government of the Northwest Territories, P.O. Box 2668, 3803 Bretzlaff Dr., Yellowknife, Northwest Territories X1A 2P9, Canada; Dean_Cluff@gov.nt.ca

${ }^{4}$ Faculty of Environmental Design, University of Calgary, Calgary, Alberta T2N 1N4, Canada; current address: P.O. Box 150, Meacham, Saskatchewan S0K 2V0, Canada

(C) The Arctic Institute of North America
} 


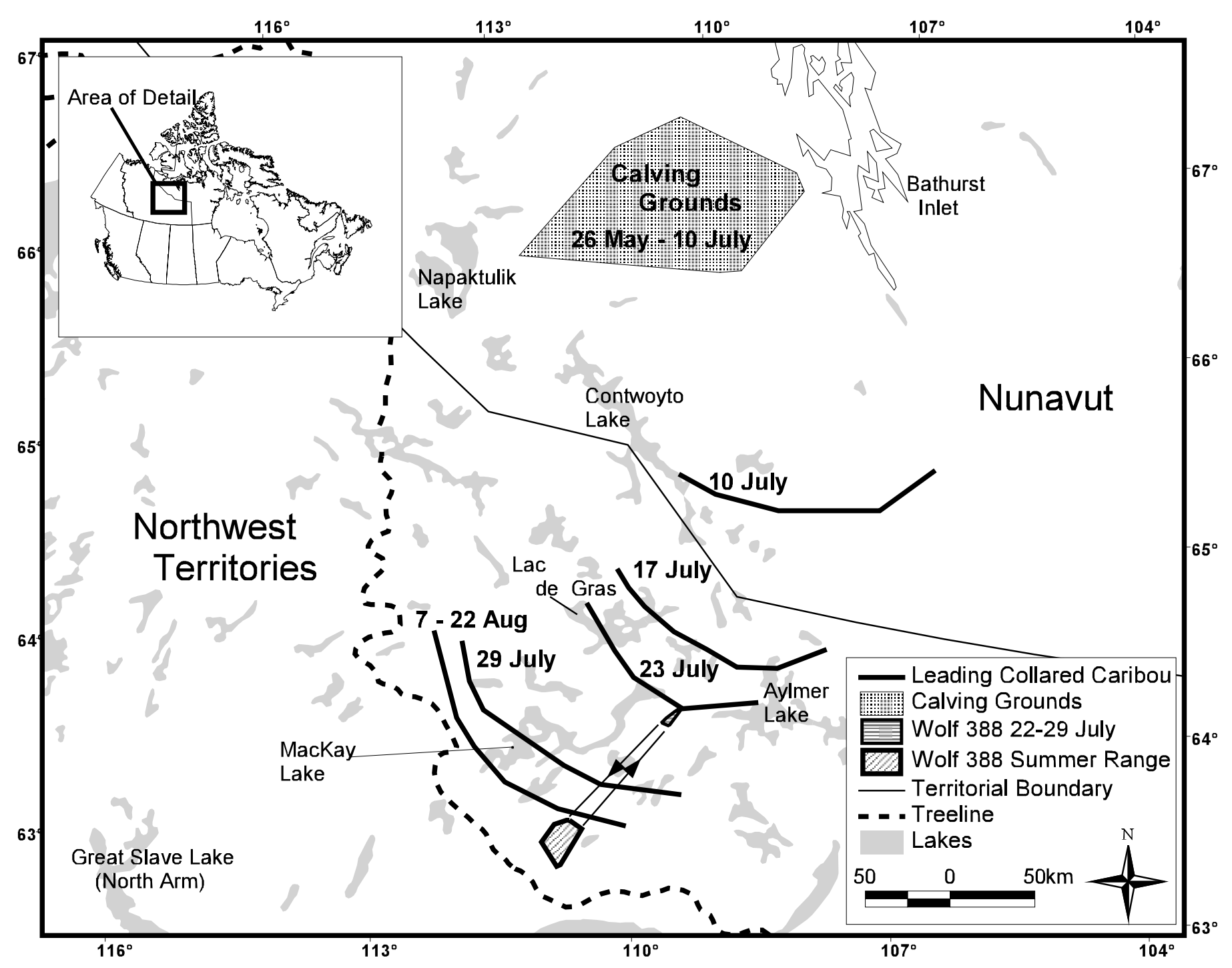

FIG. 1. Map showing the movements of satellite radio-collared caribou with respect to female wolf 388 's summer range and long foraging movement, in summer 2002.

throughout the study area. Standing water and exposed bedrock are characteristic of the area.

\section{Details of the Caribou-Wolf System}

The Bathurst caribou herd uses this study area. Most caribou cows have begun migrating by late April, reaching calving grounds by June (Gunn et al., 2001; Fig. 1). Calving peaks by 15 June (Gunn et al., 2001), and calves begin to travel with the herd by one week of age (Kelsall, 1968). The movement patterns of bulls are less known, but bulls frequent areas near calving grounds by mid-June (Heard et al., 1996; Gunn et al., 2001). In summer, Bathurst caribou cows generally travel south from their calving grounds and then, parallel to the tree line, to the northwest. The rut usually takes place at the tree line in October (Gunn et al., 2001). The winter range of the Bathurst herd varies among years, ranging through the taiga and along the tree line from south of Great Bear Lake to southeast of
Great Slave Lake. Some caribou spend the winter on the tundra (Gunn et al., 2001; Thorpe et al., 2001).

In winter, wolves that prey on Bathurst caribou do not behave territorially. Instead, they follow the herd throughout its winter range (Walton et al., 2001; Musiani, 2003). However, during denning (May-August, parturition late May to mid-June), wolf movements are limited by the need to return food to the den. To maximize access to migrating caribou, many wolves select den sites closer to the tree line than to caribou calving grounds (Heard and Williams, 1992). Because of caribou movement patterns, tundra denning wolves are separated from the main caribou herds by several hundred kilometres at some time during summer (Williams, 1990:19; Fig. 1; Table 1).

Muskoxen do not occur in the study area (Fournier and Gunn, 1998), and there are few moose there (H.D. Cluff, pers. obs.). Therefore, alternative prey for wolves includes waterfowl, other ground-nesting birds, their eggs, rodents, and hares (Kuyt, 1972; Williams, 1990:16; H.D. Cluff and 
TABLE 1. Daily distances from wolf 388 and the den to the nearest radio-collared caribou during a long excursion in summer 2002.

\begin{tabular}{lcc}
\hline \hline Date (2002) & $\begin{array}{c}\text { Mean distance from } \\
\text { caribou to wolf }(\mathrm{km})\end{array}$ & $\begin{array}{c}\text { Daily distance from } \\
\text { closest caribou to den }\end{array}$ \\
\hline 12 July & 242 & 241 \\
13 July & 210 & 209 \\
14 July & 200 & 199 \\
15 July & 186 & 180 \\
16 July & 163 & 162 \\
17 July & 151 & 148 \\
18 July & 144 & 137 \\
19 July & 126 & 124 \\
20 July & 103 & 130 \\
21 July & 73 & 130 \\
22 July & 40 & 110 \\
23 July & 9 & 104 \\
29 July & 30 & 43 \\
30 July & 16 & 43 \\
31 July & 32 & 44 \\
1 August & 28 & 46 \\
2 August & ${ }^{3}$ & 52 \\
3 August & 29 & 53 \\
4 August & 54 & 74 \\
5 August & 53 & 75 \\
6 August & 74 & 75 \\
7 August & 75 & 75 \\
8 August & 74 & 75 \\
9 August & 72 & 79 \\
\hline \hline
\end{tabular}

${ }^{1}$ Excursion starts.

${ }^{2}$ Wolf closest to collared caribou.

${ }^{3}$ Previous five days' caribou locations not available.

${ }^{4}$ Excursion ends.

P.F. Frame, unpubl. data). During 56 hours of den observations, we saw no ground squirrels or hares, only birds. It appears that the abundance of alternative prey was relatively low in 2002.

\section{METHODS}

\section{Wolf Monitoring}

We captured female wolf 388 near her den on 22 June 2002 , using a helicopter net-gun (Walton et al., 2001). She was fitted with a releasable GPS radio collar (Merrill et al., 1998) programmed to acquire locations at 30-minute intervals. The collar was electronically released (e.g., Mech and Gese, 1992) on 20 August 2002. From 27 June to 3 July 2002 , we observed 388 's den with a $78 \mathrm{~mm}$ spotting scope at a distance of $390 \mathrm{~m}$.

\section{Caribou Monitoring}

In spring of 2002, ten female caribou were captured by helicopter net-gun and fitted with satellite radio collars, bringing the total number of collared Bathurst cows to 19 . Eight of these spent the summer of 2002 south of Queen Maud Gulf, well east of normal Bathurst caribou range. Therefore, we used 11 caribou for this analysis. The collars provided one location per day during our study, except for five days from 24 to 28 July. Locations of satellite collars were obtained from Service Argos, Inc. (Landover, Maryland).

\section{Data Analysis}

Location data were analyzed by ArcView GIS software (Environmental Systems Research Institute Inc., Redlands, California). We calculated the average distance from the nearest collared caribou to the wolf and the den for each day of the study.

Wolf foraging bouts were calculated from the time 388 exited a buffer zone (500 $\mathrm{m}$ radius around the den) until she re-entered it. We considered her to be traveling when two consecutive locations were spatially separated by more than $100 \mathrm{~m}$. Minimum distance traveled was the sum of distances between each location and the next during the excursion.

We compared pre- and post-excursion data using Analysis of Variance (ANOVA; Zar, 1999). We first tested for homogeneity of variances with Levene's test (Brown and Forsythe, 1974). No transformations of these data were required.

\section{RESULTS}

\section{Wolf Monitoring}

Pre-Excursion Period: Wolf 388 was lactating when captured on 22 June. We observed her and two other females nursing a group of 11 pups between 27 June and 3 July. During our observations, the pack consisted of at least four adults ( 3 females and 1 male) and 11 pups. On 30 June, three pups were moved to a location $310 \mathrm{~m}$ from the other eight and cared for by an uncollared female. The male was not seen at the den after the evening of 30 June.

Before the excursion, telemetry indicated 18 foraging bouts. The mean distance traveled during these bouts was $25.29 \mathrm{~km}( \pm 4.5 \mathrm{SE}$, range $3.1-82.5 \mathrm{~km})$. Mean greatest distance from the den on foraging bouts was $7.1 \mathrm{~km}( \pm 0.9$ $\mathrm{SE}$, range $1.7-17.0 \mathrm{~km})$. The average duration of foraging bouts for the period was $20.9 \mathrm{~h}( \pm 4.5 \mathrm{SE}$, range $1-71 \mathrm{~h})$.

The average daily distance between the wolf and the nearest collared caribou decreased from $242 \mathrm{~km}$ on 12 July, one week before the excursion period, to $126 \mathrm{~km}$ on 19 July, the day the excursion began (Table 1).

Excursion Period: On 19 July at 2203, after spending $14 \mathrm{~h}$ at the den, 388 began moving to the northeast and did not return for $336 \mathrm{~h}$ (14 d; Fig. 2). Whether she traveled alone or with other wolves is unknown. During the excursion, $476(71 \%)$ of 672 possible locations were recorded. The wolf crossed the southeast end of Lac Capot Blanc on a small land bridge, where she paused for $4.5 \mathrm{~h}$ after traveling for $19.5 \mathrm{~h}(37.5 \mathrm{~km})$. Following this rest, she traveled for $9 \mathrm{~h}(26.3 \mathrm{~km})$ onto a peninsula in Reid Lake, where she spent $2 \mathrm{~h}$ before backtracking and stopping for $8 \mathrm{~h}$ just off the peninsula. Her next period of travel lasted $16.5 \mathrm{~h}(32.7 \mathrm{~km})$, terminating in a pause of $9.5 \mathrm{~h}$ just $3.8 \mathrm{~km}$ 


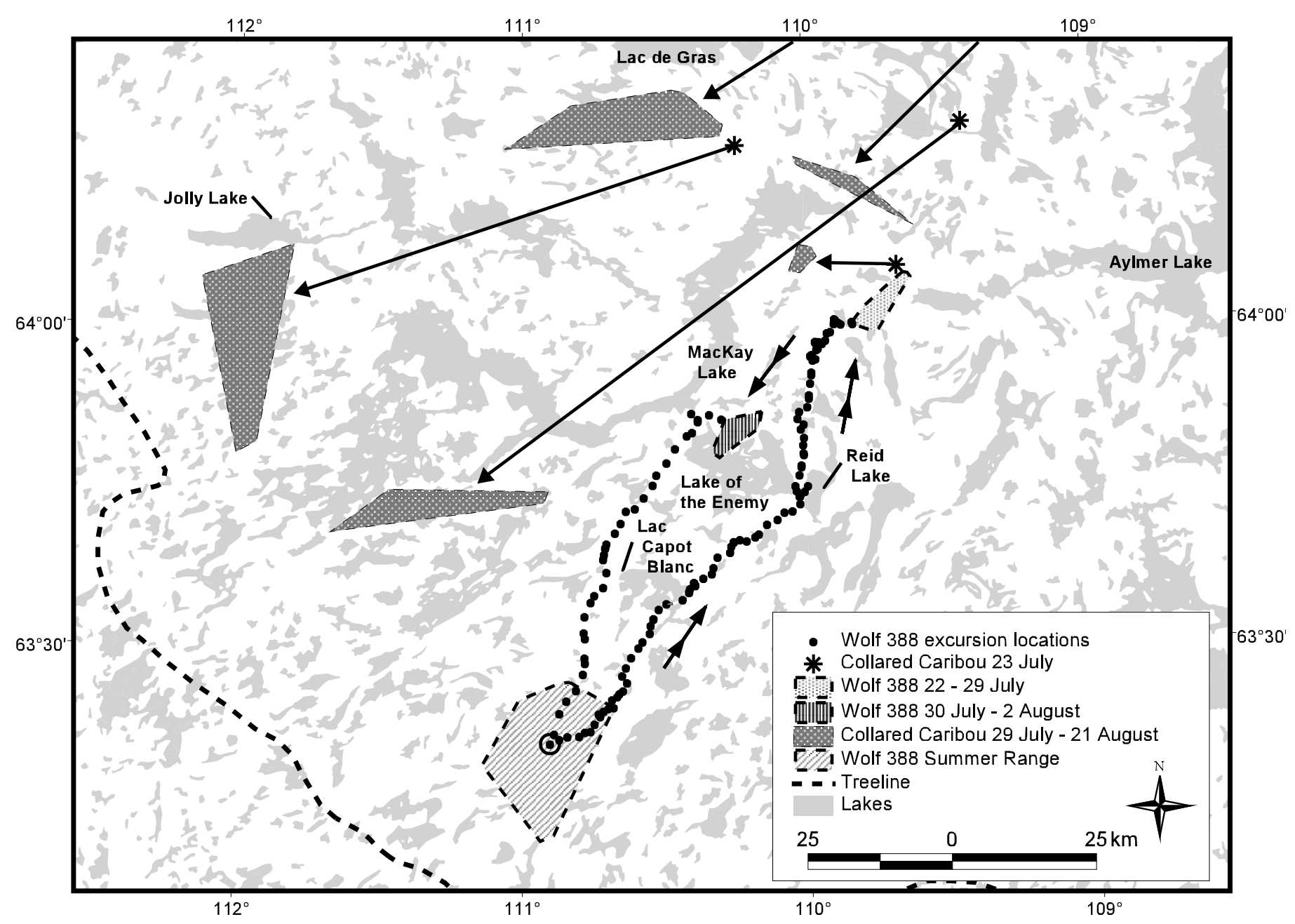

FIG. 2. Details of a long foraging movement by female wolf 388 between 19 July and 2 August 2002. Also shown are locations and movements of three satellite radio-collared caribou from 23 July to 21 August 2002. On 23 July, the wolf was $8 \mathrm{~km}$ from a collared caribou. The farthest point from the den (103 km distant) was recorded on 27 July. Arrows indicate direction of travel.

from a concentration of locations at the far end of her excursion, where we presume she encountered caribou. The mean duration of these three movement periods was $15.7 \mathrm{~h}( \pm 2.5 \mathrm{SE})$, and that of the pauses, $7.3 \mathrm{~h}( \pm 1.5)$. The

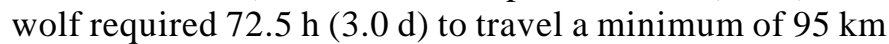
from her den to this area near caribou (Fig. 2). She remained there $\left(35.5 \mathrm{~km}^{2}\right)$ for $151.5 \mathrm{~h}(6.3 \mathrm{~d})$ and then moved south to Lake of the Enemy, where she stayed $\left(31.9 \mathrm{~km}^{2}\right)$ for $74 \mathrm{~h}(3.1 \mathrm{~d})$ before returning to her den. Her greatest distance from the den, $103 \mathrm{~km}$, was recorded $174.5 \mathrm{~h}$ (7.3 d) after the excursion began, at 0433 on 27 July. She was $8 \mathrm{~km}$ from a collared caribou on 23 July, four days after the excursion began (Table 1).

The return trip began at 0403 on 2 August, $318 \mathrm{~h}$ (13.2 d) after leaving the den. She followed a relatively direct path for $18 \mathrm{~h}$ back to the den, a distance of $75 \mathrm{~km}$.

The minimum distance traveled during the excursion was $339 \mathrm{~km}$. The estimated overall minimum travel rate was $3.1 \mathrm{~km} / \mathrm{h}, 2.6 \mathrm{~km} / \mathrm{h}$ away from the den and $4.2 \mathrm{~km} / \mathrm{h}$ on the return trip.
Post-Excursion Period: We saw three pups when recovering the collar on 20 August, but others may have been hiding in vegetation.

Telemetry recorded 13 foraging bouts in the post-excursion period. The mean distance traveled during these bouts was $18.3 \mathrm{~km}(+2.7 \mathrm{SE}$, range $1.2-47.7 \mathrm{~km})$, and mean greatest distance from the den was $7.1 \mathrm{~km}(+0.7 \mathrm{SE}$, range $1.1-11.0 \mathrm{~km})$. The mean duration of these post-excursion foraging bouts was $10.9 \mathrm{~h}(+2.4 \mathrm{SE}$, range $1-33 \mathrm{~h})$.

When 388 reached her den on 2 August, the distance to the nearest collared caribou was $54 \mathrm{~km}$. On 9 August, one week after she returned, the distance was $79 \mathrm{~km}$ (Table 1).

\section{Pre- and Post-Excursion Comparison}

We found no differences in the mean distance of foraging bouts before and after the excursion period $(\mathrm{F}=1.5$, $\mathrm{df}=1,29, p=0.24)$. Likewise, the mean greatest distance from the den was similar pre- and post-excursion ( $\mathrm{F}=$ $0.004, \mathrm{df}=1,29, p=0.95)$. However, the mean duration of 
388's foraging bouts decreased by $10.0 \mathrm{~h}$ after her long excursion $(\mathrm{F}=3.1, \mathrm{df}=1,29, p=0.09)$.

\section{Caribou Monitoring}

Summer Movements: On 10 July, 5 of 11 collared caribou were dispersed over a distance of $10 \mathrm{~km}, 140 \mathrm{~km}$ south of their calving grounds (Fig. 1). On the same day, three caribou were still on the calving grounds, two were between the calving grounds and the leaders, and one was missing. One week later (17 July), the leading radiocollared cows were $100 \mathrm{~km}$ farther south (Fig. 1). Two were within $5 \mathrm{~km}$ of each other in front of the rest, who were more dispersed. All radio-collared cows had left the calving grounds by this time. On 23 July, the leading radiocollared caribou had moved $35 \mathrm{~km}$ farther south, and all of them were more widely dispersed. The two cows closest to the leader were $26 \mathrm{~km}$ and $33 \mathrm{~km}$ away, with $37 \mathrm{~km}$ between them. On the next location (29 July), the most southerly caribou were $60 \mathrm{~km}$ farther south. All of the caribou were now in the areas where they remained for the duration of the study (Fig. 2).

A Minimum Convex Polygon (Mohr and Stumpf, 1966) around all caribou locations acquired during the study encompassed $85119 \mathrm{~km}^{2}$.

Relative to the Wolf Den: The distance from the nearest collared caribou to the den decreased from $241 \mathrm{~km}$ one week before the excursion to $124 \mathrm{~km}$ the day it began. The nearest a collared caribou came to the den was $43 \mathrm{~km}$ away, on 29 and 30 July. During the study, four collared caribou were located within $100 \mathrm{~km}$ of the den. Each of these four was closest to the wolf on at least one day during the period reported.

\section{DISCUSSION}

\section{Prey Abundance}

Caribou are the single most important prey of tundra wolves (Clark, 1971; Kuyt, 1972; Stephenson and James, 1982; Williams, 1990). Caribou range over vast areas, and for part of the summer, they are scarce or absent in wolf home ranges (Heard et al., 1996). Both the long distance between radio-collared caribou and the den the week before the excursion and the increased time spent foraging by Wolf 388 indicate that caribou availability near the den was low. Observations of the pups' being left alone for up to $18 \mathrm{~h}$, presumably while adults were searching for food, provide additional support for low caribou availability locally. Mean foraging bout duration decreased by $10.0 \mathrm{~h}$ after the excursion, when collared caribou were closer to the den, suggesting an increase in caribou availability nearby.

\section{Foraging Excursion}

One aspect of central place foraging theory (CPFT) deals with the optimality of returning different-sized food loads from varying distances to dependents at a central place (i.e., the den) (Orians and Pearson, 1979). Carlson (1985) tested CPFT and found that the predator usually consumed prey captured far from the central place, while feeding prey captured nearby to dependants. Wolf 388 spent 7.2 days in one area near caribou before moving to a location $23 \mathrm{~km}$ back towards the den, where she spent an additional 3.1 days, likely hunting caribou. She began her return trip from this closer location, traveling directly to the den. While away, she may have made one or more successful kills and spent time meeting her own energetic needs before returning to the den. Alternatively, it may have taken several attempts to make a kill, which she then fed on before beginning her return trip. We do not know if she returned food to the pups, but such behavior would be supported by CPFT.

Other workers have reported wolves' making long round trips and referred to them as "extraterritorial" or "pre-dispersal" forays (Fritts and Mech, 1981; Messier, 1985; Ballard et al., 1997; Merrill and Mech, 2000). These movements are most often made by young wolves ( $1-3$ years old), in areas where annual territories are maintained and prey are relatively sedentary (Fritts and Mech, 1981; Messier, 1985). The long excursion of 388 differs in that tundra wolves do not maintain annual territories (Walton et al., 2001), and the main prey migrate over vast areas (Gunn et al., 2001).

Another difference between 388's excursion and those reported earlier is that she is a mature, breeding female. No study of territorial wolves has reported reproductive adults making extraterritorial movements in summer (Fritts and Mech, 1981; Messier, 1985; Ballard et al., 1997; Merrill and Mech, 2001). However, Walton et al. (2001) also report that breeding female tundra wolves made excursions.

\section{Direction of Movement}

Possible explanations for the relatively direct route 388 took to the caribou include landscape influence and experience. Considering the timing of 388's trip and the locations of caribou, had the wolf moved northwest, she might have missed the caribou entirely, or the encounter might have been delayed.

A reasonable possibility is that the land directed 388's route. The barrens are crisscrossed with trails worn into the tundra over centuries by hundreds of thousands of caribou and other animals (Kelsall, 1968; Thorpe et al., 2001). At river crossings, lakes, or narrow peninsulas, trails converge and funnel towards and away from caribou calving grounds and summer range. Wolves use trails for travel (Paquet et al., 1996; Mech and Boitani, 2003; P. Frame, pers. observation). Thus, the landscape may direct an animal's movements and lead it to where cues, such as the odor of caribou on the wind or scent marks of other wolves, may lead it to caribou.

Another possibility is that 388 knew where to find caribou in summer. Sexually immature tundra wolves sometimes follow caribou to calving grounds (D. Heard, 
unpubl. data). Possibly, 388 had made such journeys in previous years and killed caribou. If this were the case, then in times of local prey scarcity she might travel to areas where she had hunted successfully before. Continued monitoring of tundra wolves may answer questions about how their food needs are met in times of low caribou abundance near dens.

Caribou often form large groups while moving south to the tree line (Kelsall, 1968). After a large aggregation of caribou moves through an area, its scent can linger for weeks (Thorpe et al., 2001:104). It is conceivable that 388 detected caribou scent on the wind, which was blowing from the northeast on 19-21 July (Environment Canada, 2003), at the same time her excursion began. Many factors, such as odor strength and wind direction and strength, make systematic study of scent detection in wolves difficult under field conditions (Harrington and Asa, 2003). However, humans are able to smell odors such as forest fires or oil refineries more than $100 \mathrm{~km}$ away. The olfactory capabilities of dogs, which are similar to wolves, are thought to be 100 to 1 million times that of humans (Harrington and Asa, 2003). Therefore, it is reasonable to think that under the right wind conditions, the scent of many caribou traveling together could be detected by wolves from great distances, thus triggering a long foraging bout.

\section{Rate of Travel}

Mech (1994) reported the rate of travel of Arctic wolves on barren ground was $8.7 \mathrm{~km} / \mathrm{h}$ during regular travel and $10.0 \mathrm{~km} / \mathrm{h}$ when returning to the den, a difference of $1.3 \mathrm{~km} / \mathrm{h}$. These rates are based on direct observation and exclude periods when wolves moved slowly or not at all. Our calculated travel rates are assumed to include periods of slow movement or no movement. However, the pattern we report is similar to that reported by Mech (1994), in that homeward travel was faster than regular travel by $1.6 \mathrm{~km} / \mathrm{h}$. The faster rate on return may be explained by the need to return food to the den. Pup survival can increase with the number of adults in a pack available to deliver food to pups (Harrington et al., 1983). Therefore, an increased rate of travel on homeward trips could improve a wolf's reproductive fitness by getting food to pups more quickly.

\section{Fate of 388's Pups}

Wolf 388 was caring for pups during den observations. The pups were estimated to be six weeks old, and were seen ranging as far as $800 \mathrm{~m}$ from the den. They received some regurgitated food from two of the females, but were unattended for long periods. The excursion started 16 days after our observations, and it is improbable that the pups could have traveled the distance that 388 moved. If the pups died, this would have removed parental responsibility, allowing the long movement.

Our observations and the locations of radio-collared caribou indicate that prey became scarce in the area of the den as summer progressed. Wolf 388 may have abandoned her pups to seek food for herself. However, she returned to the den after the excursion, where she was seen near pups. In fact, she foraged in a similar pattern before and after the excursion, suggesting that she again was providing for pups after her return to the den.

A more likely possibility is that one or both of the other lactating females cared for the pups during 388's absence. The three females at this den were not seen with the pups at the same time. However, two weeks earlier, at a different den, we observed three females cooperatively caring for a group of six pups. At that den, the three lactating females were observed providing food for each other and trading places while nursing pups. Such a situation at the den of 388 could have created conditions that allowed one or more of the lactating females to range far from the den for a period, returning to her parental duties afterwards. However, the pups would have been weaned by eight weeks of age (Packard et al., 1992), so nonlactating adults could also have cared for them, as often happens in wolf packs (Packard et al., 1992; Mech et al., 1999).

Cooperative rearing of multiple litters by a pack could create opportunities for long-distance foraging movements by some reproductive wolves during summer periods of local food scarcity. We have recorded multiple lactating females at one or more tundra wolf dens per year since 1997. This reproductive strategy may be an adaptation to temporally and spatially unpredictable food resources. All of these possibilities require further study, but emphasize both the adaptability of wolves living on the barrens and their dependence on caribou.

Long-range wolf movement in response to caribou availability has been suggested by other researchers (Kuyt, 1972; Walton et al., 2001) and traditional ecological knowledge (Thorpe et al., 2001). Our report demonstrates the rapid and extreme response of wolves to caribou distribution and movements in summer. Increased human activity on the tundra (mining, road building, pipelines, ecotourism) may influence caribou movement patterns and change the interactions between wolves and caribou in the region. Continued monitoring of both species will help us to assess whether the association is being affected adversely by anthropogenic change.

\section{ACKNOWLEDGEMENTS}

This research was supported by the Department of Resources, Wildlife, and Economic Development, Government of the Northwest Territories; the Department of Biological Sciences at the University of Alberta; the Natural Sciences and Engineering Research Council of Canada; the Department of Indian and Northern Affairs Canada; the Canadian Circumpolar Institute; and DeBeers Canada, Ltd. Lorna Ruechel assisted with den observations. A. Gunn provided caribou location data. We thank Dave Mech for the use of GPS collars. M. Nelson, A. Gunn, and three anonymous reviewers made helpful comments on earlier drafts of the manuscript. This work 
was done under Wildlife Research Permit - WL002948 issued by the Government of the Northwest Territories, Department of Resources, Wildlife, and Economic Development.

\section{REFERENCES}

BALLARD, W.B., AYRES, L.A., KRAUSMAN, P.R., REED, D.J., and FANCY, S.G. 1997. Ecology of wolves in relation to a migratory caribou herd in northwest Alaska. Wildlife Monographs $135.47 \mathrm{p}$.

BROWN, M.B., and FORSYTHE, A.B. 1974. Robust tests for the equality of variances. Journal of the American Statistical Association 69:364-367.

CARLSON, A. 1985. Central place foraging in the red-backed shrike (Lanius collurio L.): Allocation of prey between forager and sedentary consumer. Animal Behaviour 33:664-666.

CLARK, K.R.F. 1971. Food habits and behavior of the tundra wolf on central Baffin Island. Ph.D. Thesis, University of Toronto, Ontario, Canada.

ENVIRONMENT CANADA. 2003. National climate data information archive. Available online: http://www.climate. weatheroffice.ec.gc.ca/Welcome_e.html

FOURNIER, B., and GUNN, A. 1998. Musk ox numbers and distribution in the NWT, 1997. File Report No. 121. Yellowknife: Department of Resources, Wildlife, and Economic Development, Government of the Northwest Territories. $55 \mathrm{p}$.

FRITTS, S.H., and MECH, L.D. 1981. Dynamics, movements, and feeding ecology of a newly protected wolf population in northwestern Minnesota. Wildlife Monographs 80. 79 p.

GUNN, A., DRAGON, J., and BOULANGER, J. 2001. Seasonal movements of satellite-collared caribou from the Bathurst herd. Final Report to the West Kitikmeot Slave Study Society, Yellowknife, NWT. 80 p. Available online: http:// www.wkss.nt.ca/HTML/08_ProjectsReports/PDF/Seasonal MovementsFinal.pdf

HARRINGTON, F.H., and ASA, C.S. 2003. Wolf communication. In: Mech, L.D., and Boitani, L., eds. Wolves: Behavior, ecology, and conservation. Chicago: University of Chicago Press. 66103.

HARRINGTON, F.H., MECH, L.D., and FRITTS, S.H. 1983. Pack size and wolf pup survival: Their relationship under varying ecological conditions. Behavioral Ecology and Sociobiology 13:19-26.

HARRIS, S.A. 1986. Permafrost distribution, zonation and stability along the eastern ranges of the cordillera of North America. Arctic 39(1):29-38.

HEARD, D.C., and WILLIAMS, T.M. 1992. Distribution of wolf dens on migratory caribou ranges in the Northwest Territories, Canada. Canadian Journal of Zoology 70:1504-1510.

HEARD, D.C., WILLIAMS, T.M., and MELTON, D.A. 1996. The relationship between food intake and predation risk in migratory caribou and implication to caribou and wolf population dynamics. Rangifer Special Issue No. 2:37-44.

KELSALL, J.P. 1968. The migratory barren-ground caribou of Canada. Canadian Wildlife Service Monograph Series 3. Ottawa: Queen's Printer. 340 p.
KUYT, E. 1962. Movements of young wolves in the Northwest Territories of Canada. Journal of Mammalogy 43:270-271. 1972. Food habits and ecology of wolves on barren-ground caribou range in the Northwest Territories. Canadian Wildlife Service Report Series 21. Ottawa: Information Canada. 36 p.

MECH, L.D. 1994. Regular and homeward travel speeds of Arctic wolves. Journal of Mammalogy 75:741-742.

MECH, L.D., and BOITANI, L. 2003. Wolf social ecology. In: Mech, L.D., and Boitani, L., eds. Wolves: Behavior, ecology, and conservation. Chicago: University of Chicago Press. 1-34.

MECH, L.D., and GESE, E.M. 1992. Field testing the Wildlink capture collar on wolves. Wildlife Society Bulletin 20:249256.

MECH,L.D., WOLFE, P., and PACKARD, J.M. 1999. Regurgitative food transfer among wild wolves. Canadian Journal of Zoology 77:1192-1195.

MERRILL, S.B., and MECH, L.D. 2000. Details of extensive movements by Minnesota wolves (Canis lupus). American Midland Naturalist 144:428-433.

MERRILL, S.B., ADAMS, L.G., NELSON, M.E., and MECH, L.D. 1998. Testing releasable GPS radiocollars on wolves and white-tailed deer. Wildlife Society Bulletin 26:830-835.

MESSIER, F. 1985. Solitary living and extraterritorial movements of wolves in relation to social status and prey abundance. Canadian Journal of Zoology 63:239-245.

MOHR, C.O., and STUMPF, W.A. 1966. Comparison of methods for calculating areas of animal activity. Journal of Wildlife Management 30:293-304.

MUSIANI, M. 2003. Conservation biology and management of wolves and wolf-human conflicts in western North America. Ph.D. Thesis, University of Calgary, Calgary, Alberta, Canada.

ORIANS, G.H., and PEARSON, N.E. 1979. On the theory of central place foraging. In: Mitchell, R.D., and Stairs, G.F., eds. Analysis of ecological systems. Columbus: Ohio State University Press. 154-177.

PACKARD, J.M., MECH, L.D., and REAM, R.R. 1992. Weaning in an arctic wolf pack: Behavioral mechanisms. Canadian Journal of Zoology 70:1269-1275.

PAQUET, P.C., WIERZCHOWSKI, J., and CALLAGHAN, C. 1996. Summary report on the effects of human activity on gray wolves in the Bow River Valley, Banff National Park, Alberta. In: Green, J., Pacas, C., Bayley, S., and Cornwell, L., eds. A cumulative effects assessment and futures outlook for the Banff Bow Valley. Prepared for the Banff Bow Valley Study. Ottawa: Department of Canadian Heritage.

STEPHENSON, R.O., and JAMES, D. 1982. Wolf movements and food habits in northwest Alaska. In: Harrington, F.H., and Paquet, P.C., eds. Wolves of the world. New Jersey: Noyes Publications. 223-237.

THORPE, N., EYEGETOK, S., HAKONGAK, N., and QITIRMIUT ELDERS. 2001. The Tuktu and Nogak Project: A caribou chronicle. Final Report to the West Kitikmeot/Slave Study Society, Ikaluktuuttiak, NWT. 160 p.

TIMONEY, K.P., LA ROI, G.H., ZOLTAI, S.C., and ROBINSON, A.L. 1992. The high subarctic forest-tundra of northwestern Canada: Position, width, and vegetation gradients in relation to climate. Arctic 45(1):1-9. 
FORAGING MOVEMENT OF A TUNDRA WOLF • 203

WALTON, L.R., CLUFF, H.D., PAQUET, P.C., and RAMSAY, M.A. 2001. Movement patterns of barren-ground wolves in the central Canadian Arctic. Journal of Mammalogy 82:867-876.

WILLIAMS, T.M. 1990. Summer diet and behavior of wolves denning on barren-ground caribou range in the Northwest
Territories, Canada. M.Sc. Thesis, University of Alberta, Edmonton, Alberta, Canada.

ZAR, J.H. 1999. Biostatistical analysis. 4th ed. New Jersey: Prentice Hall. 663 p. 